\title{
Stage-Based Challenges and Strategies for Support in Doctoral Education: A Practical Guide for Students, Faculty Members, and Program Administrators
}

\author{
Meghan J. Pifer \\ Widener University, \\ Chester, PA, USA
}

mipifer@widener.edu

\author{
Vicki L. Baker \\ Albion College, \\ Albion, MI, USA \\ vbaker@albion.edu
}

\begin{abstract}
Studies of doctoral education have included an interest not only in processes, structures, and outcomes, but also in students' experiences. There are often useful recommendations for practice within individual examinations of the doctoral experience, yet there remains a need to strengthen the application of lessons from research to the behaviors of students and others engaged in the doctoral process. This paper is the first to synthesize research about doctoral education with the particular aim of informing practical strategies for multiple stakeholders.

In this article, we summarize findings from a literature review of the scholarship about doctoral education from the past 15 years in a stage-based overview of the challenges of doctoral education. Our aim is to apply theory to practice through the systematic consideration of how research about doctoral education can best inform students and those who support them in the doctoral journey. We first present an overview of the major stages of doctoral education and related challenges identified in the research. We then consider key findings of that research to offer recommendations for doctoral students, faculty members, and administrators within and across stages.
\end{abstract}

Keywords: doctoral education, doctoral student experiences, faculty members, administrators, challenges, strategies for success

\section{Introduction}

Doctoral education serves as a training ground for scholars and researchers. Across the disciplines, doctoral programs provide a professional labor force that advances national and interna-

Material published as part of this publication, either on-line or in print, is copyrighted by the Informing Science Institute. Permission to make digital or paper copy of part or all of these works for personal or classroom use is granted without fee provided that the copies are not made or distributed for profit or commercial advantage AND that copies 1) bear this notice in full and 2) give the full citation on the first page. It is permissible to abstract these works so long as credit is given. To copy in all other cases or to republish or to post on a server or to redistribute to lists requires specific permission and payment of a fee. Contact Publisher@InformingScience.org to request redistribution permission. tional intellectual and economic development through both academic and nonacademic careers. Doctoral education is also a topic of growing importance, given questions about implementation costs, program effectiveness and purposes, time to degree, internationalization, and equity and diversity (Brailsford, 2010; Council of Graduate Schools and Educational Testing Service, 2010; Doan, Nathans, Anderson, \& Bial, 2013; 
Golde \& Walker, 2006; Labi, 2010; National Science Foundation, National Center for Science and Engineering Statistics, 2015).

New knowledge continues to improve doctoral education (e.g., Hutchings \& Clarke, 2004; PruittLogan, \& Gaff, 2004), yet the connection between research and practice remains critical (Council of Graduate Schools and Educational Testing Service, 2010; Lovitts, 2004; National Science Foundation, n.d.). Investing in new knowledge about and assessment of doctoral education is only the first step; the return on that investment will come only when the resultant knowledge and better data are fed back into the world of practice. The evolution of doctoral education is dependent upon not just research, but also the efforts of the full range of stakeholders and participants in graduate education. As Wulff, Austin, and associates (2004) concluded, "university leaders, professors, and leaders of professional associations and foundations must think practically and critically about the paths to the professoriate and strategies for enriching the preparation of future faculty" (p. 12). Yet, researchers including Heathcott (2007) and Walker, Golde, Jones, Bueschel, and Hutchings (2008) have described challenges in implementing recommendations stemming from insufficient knowledge of program effectiveness and needs within institutions.

Research about doctoral education favors a stage model approach, which delineates transitions according to major tasks and program milestones (Tinto, 1993; Weidman Twale, \& Stein, 2001). At the doctoral level, stages are components of the educational process "that mark key transition points in students' progress toward the PhD" (Lovitts, 2001, p.40). While they do not come without their criticisms (Dall'Alba \& Sandberg, 2006), stage models have served an important purpose in understanding students' development and experiences in academic settings. Tinto (1993) may have been the first to offer the stage model of doctoral education, which actually appeared as an appendix to his book about undergraduate education. In that model, Tinto (1993) argued for research about community- and structural-based strategies for supporting doctoral student persistence. He conceptualized the stages of doctoral education as transition, candidacy, and completion. Gardner (2009b) followed a similar model, using the labels of entry, integration, and candidacy. Weidman et al.'s (2001) popular stage model of graduate and professional student socialization diverged from that somewhat in defining stages as "different states of identity and commitment that are overlapping rather than mutually exclusive" (p. 11). Their model was based on four stages of anticipatory, formal, informal, and personal socialization in doctoral education. The stages of doctoral education have been theorized, defined, and labeled in slightly different ways. We rely on the 3-stage model and the labels of knowledge consumption, knowledge creation, and knowledge enactment.

Researchers of doctoral education have sought to understand the various challenges of each stage of the process, as well as those that may occur across stages. In most doctoral programs, students are guided through discipline-specific goals as they demonstrate expertise and work towards degree completion. While this is similar to the traditional four-year model of undergraduate education that has guided practice in the United States and elsewhere, far less research has explored the effects and implications of doctoral education models, and the link between research and practice in this area is underdeveloped. University and program administrators, faculty members, and doctoral students may be further behind than their peers in undergraduate education in applying research-based knowledge of these stages to strategies of practice and student support. Our aim is to link current knowledge of these stages to specific recommendations for these three stakeholder groups, so as to narrow that gap between research and practice.

This article synthesizes the scholarly literature about the challenges of doctoral education with the aim of supporting those interested in understanding and improving the doctoral student experience from practice-based perspectives. Our attention to practice includes the three main stakeholders engaged in the doctoral education journey - doctoral students themselves, faculty members, and program directors and other administrators. We have a particular interest in equipping 
students for successful strategies to respond to the challenges of doctoral education. By reviewing scholarly research articles about doctoral education, we consider key findings about the doctoral journey through the often-applied stage model of doctoral education. From there, we repeat our synthesis with the second aim of integrating and building upon the individual recommendations for response strategies that have emerged from these studies. This study was guided by the following research questions:

1) What stage-based challenges of doctoral education have been identified in the scholarly literature?

2) What strategies for managing these challenges across and within stages emerge from this body of literature?

2a) What strategies might doctoral students employ?

2b) What strategies might faculty members employ?

2c) What strategies might administrators employ?

\section{Methods}

There were two phases to the review of the literature reported in this article. First, we used the ProQuest database to identify scholarly resources published between 2000 and 2015 using the search term doctoral education. We chose the 15-year timeframe based on the broad scope of doctoral education across the decades, the increasing scholarly attention to the topic in recent years, and our aim of synthesizing recent research towards the development of appropriate and timely recommendations for practice; the new millennium served as a point of demarcation. That query generated 1,646 results, including full-text, peer-reviewed publications. We carefully reviewed the titles, keywords, and abstracts of the first 500 publications to identify those that addressed experiences and challenges in some way, eliminating research that focused on issues such as program descriptions, national trends, or policy recommendations. Upon reviewing the first 500 results, we reached saturation in key themes. That review resulted in the final inclusion of 105 scholarly publications about doctoral education in this literature review.

We then organized the challenges identified in that body of literature according to the 3 -stage model. In the second phase of analysis, we revisited the same body of scholarship to codify the recommendations for students, faculty members, and administrators within and across stages. We also drew from those syntheses to offer any additional strategies for responding to the challenges of doctoral education that were inferred or emergent from the collective literature.

\section{Limitations}

There are several limitations to this literature review. First, while we engaged in a broad search for literature about doctoral education, this body of research is predominantly rooted in US models and programs. To the extent possible, we applied studies of non-US models to our synthesis. It is important to note, of course, that the stage model as it is typically structured in the US is not an accurate reflector of all doctoral models globally. Future studies should consider opportunities to synthesize non-US literature about challenges and strategies in doctoral education.

Second, the majority of the doctoral education literature emphasizes traditional models and students. We did not find much literature about nontraditional students such as part-time learners, nontraditional programs such as professional programs, or nontraditional delivery models such as executive programs and online programs. These findings may not be generalizable to all students in all programs. 
Third, as researchers of doctoral student experiences rooted in the stage model, we frame this analysis from our perspectives and it is influenced by our scholarly biases. We recognize there are many other frameworks from which to study the doctoral journey and that our interpretation of the literature is only one way of exploring the issues we consider here.

\section{Findings}

We organize our findings according to the three stages of doctoral education, knowledge consumption, knowledge creation, and knowledge enactment, with a fourth section addressing challenges that may occur across stages. For each, we include an overview of the key milestones and common challenges of that stage, followed by a synthesis of recommendations from the scholarly literature about response strategies for students, faculty members, and administrators.

\section{Stage 1: Knowledge Consumption}

In the first stage of doctoral education, the admission process through the first year of coursework, students begin to cultivate their identities as doctoral-level learners. The early stage of the doctoral journal may include a rough transition into the learner role. This initial transition may bring challenges related to identity shifts from professional to student, changes in geographic locations, and generally adjusting to their new roles as nascent disciplinary members (Gardner, 2009b; Sweitzer, 2009; Vekkaila, Pyhältö, \& Lonka, 2013). At this stage, students with career experience shed their prior professional identities. This may present a challenge as students do away with, or put on hold, hard-earned status and expertise and assume the identity of the novice and the new entrant into departmental, institutional, and disciplinary cultures (J. Austin et al., 2009; Gardner, 2009b; Sweitzer, 2009). In addition, the magnitude of the scholarly pursuit may come with feelings of fear, doubt, and isolation (Brill, Balcanoff, Land, Gogarty, \& Turner, 2014), in addition to exhaustion, cynicism, and inefficiency (Vekkaila et al., 2013).

Also at this time, students learn the sociocultural norms and expectations of their fields, as well as the requirements and structural guidelines of their programs. First-year coursework provides foundational content knowledge, and communicates faculty expectations for student engagement and performance. Students engage in the traditional approach to learning, whereby the professor imparts foundational knowledge through classroom instruction. Acquiring this knowledge is the first step towards legitimacy in their chosen fields. Curricular expectations and disciplinary knowledge norms as communicated through coursework may challenge students considerably (Gardner, 2009b).

\section{Stage 1 strategies for students}

We suggest that students conduct a needs assessment to identify the areas for which they need support, as well as the types of relationships that can provide that support (Baker, Pifer, \& Griffin, 2014; Martinsuo \& Turkulainen, 2011). This process, once implemented, can be repeated as needed across the stages of students' doctoral programs. This is an important stage to establish the advising, mentoring, and peer support relationships that will be instrumental throughout the doctoral journey (J. Austin et al., 2009; Baker \& Pifer, 2011; Stubb, Pyhältö, \& Lonka, 2014). Students and their doctoral supervisors don't always share perceptions and expectations of their own and each others' roles (Holbrook et al., 2014; Wade-Benzoni, Rousseau, \& Li, 2006; Woolderink, Putnik, van der Boom, \& Klabbers, 2015); taking the initiative to inquire with their supervisors at this stage of the journey may help establish a shared understanding that reduces ambiguity and provides structure to that key relationship (Main, 2014). Additionally, this is a good time for students to become familiar with key disciplinary associations as they seek to become familiar with disciplinary norms and cross-institutional networks. Early participation in disciplinary meetings will also allow students to begin creating and cultivating their developmen- 
tal networks, which will help combat the isolation that accompanies Stage 2 and will facilitate the research and job search tasks in Stage 3 (Adegbola, 2014; Sweitzer, 2009; Yerkes, Van de Schoot, \& Sonneveld, 2012).

\section{Stage 1 strategies for faculty members}

Faculty members in doctoral programs assume the individual and collective responsibility for the development of the whole student (Bair, Grant Haworth, \& Sandfort, 2004; Jones, 2013). As Heathcott (2007) wrote, "After all, we are responsible in some measure for a major part of the lives of graduate students. Our actions, conduct, and comportment contribute immeasurably to their confidence, stability, mental health, and trust" (p. 51). We suggest that faculty members collaborate with their students in the initial needs assessment process (Baker, Pifer, \& Griffin, 2014; Stubb et al., 2014). Students don't know what they don't know, particularly in the novice stage. The advice of an expert can be instrumental in teaching students how to plan and what questions to ask about their curricula and out-of class learning, professional associations and networking, and career goals and options. For instance, students may have initial perceptions about the academic job market that inaccurate or unrealistic. Being clear about expectations in advising and supervisory relationships, work styles and preferences, and overall interest and willingness to serve as members of a student's developmental network can be helpful (Lovitts, 2004). Faculty members, collectively and individually within programs, might consider the ways in which they can support entering doctoral students who may not desire or obtain academic employment upon program completion. Similarly, they might determine the degree to which they are able to support nontraditional learners in part-time and/or online degree programs as they begin their doctoral journeys (Gardner \& Gopaul, 2012; Lee \& Fottler, 2007; Woolley, 2010).

\section{Stage 1 strategies for administrators}

Institutional leaders, department chairs, and doctoral program administrators can also employ strategies to improve students' experiences, as well as those faculty members who facilitate doctoral education. Cohen (2006) wrote of administrative and organizational underdevelopment as one challenge of doctoral education, "Although outstanding champions for improving doctoral education can be found throughout graduate faculties of all institutions, they may lack the organizational structures within which to pursue change collectively and effectively" (p. 48). For many students, there is an opportunity cost to pursuing the doctorate and financial support is critical (Kärner, Kukemelk, Herdlein, 2005; Solem, Lee, \& Schlemper, 2009). In this first stage, administrative support manifests itself through funding for graduate assistantships and fellowships, office space and physical resources such as technology or lab equipment, and clear and effective admissions practices (Lovitts, 2004). While these administrative supports are necessary throughout students' programs, they may be particularly important in recruiting and retaining students in the initial stage. Formal orientation programs are, of course, of particular value at this stage (J. Austin et al., 2009; Gardner, 2009a; Lovitts, 2004; Washburn-Moses, 2008; Weidman et al., 2001). Administrative responses might also include the allocation of resources towards marketing, recruitment, and admissions procedures that demonstrate a perceived value of nonacademic post-doctoral career choices (Lee \& Fottler, 2007). Policies such as initial advisor assignments, the awarding of fellowships or student grants, and assignments to research teams are critical for student success at this stage. While graduate admissions policies and capital resource budgets are likely to come from institutional leaders, program administrators and department chairs can advocate for student success by facilitating conversations among graduate faculty members about best practices for recruiting and selecting students and the classroom-based learning that occurs in Stage 1. 


\section{Stage 2: Knowledge Creation}

Stage 2 includes the completion of coursework, candidacy exams, and the dissertation proposal development and defense. Such significant tasks can bring with them equally significant fears, concerns, and self-doubt. Research has revealed the potential difficulty in transitioning to independence as students engage in the development of their scholarly identities, professional skills, and research agendas (Baker, Pifer, \& Flemion, 2013; Gardner, 2009b; Lovitts, 2005; Walker et al., 2008). This can be an isolating time, yet research suggests that academic integration is critical for persistence (Golde, 2000, 2005). There is often no precedent for the type of activity and responsibilities students encounter in Stage 2 as they move away from the structure provided by courses. No longer prompted by responsibilities such as attending class or collaborating on assignments, interactions with faculty and fellow students can become infrequent. Students' relationships, both within and outside the academic program, must evolve to accommodate this transition. Work with faculty members shifts during this stage from structured dialogues in the classroom to the unstructured nature of collaboration and supervision that occurs in research projects, writing, and dissertation work. Interactions with family and friends can also become strained or less frequent if time for personal relationships is sacrificed for research and writing (Baker \& Pifer, 2011; Gardner \& Gopaul, 2012).

\section{Stage 2 strategies for students}

The pressure to develop professionally, while still completing their training in the new autonomy of Stage 2, can be overwhelming. Recognizing and understanding this stage can help students manage its challenges effectively. It is normal to feel uneasy with the rapid, ill defined, and sometimes confusing transition from coursework to independent scholarship. Stage 2 is a useful time for applying prior learning to the construction of their own scholarship, research agendas, expertise, and professional identities (Baker, Pifer, \& Flemion, 2013). It is important for students to be proactive about communicating in both personal and professional relationships during Stage 2. One of the most important relationships is that with the advisor or dissertation chair (Barnes \& Austin, 2009; Gardner, 2008; McAlpine \& Amundsen, 2012). Students who are able to let their advisors know what they expect from those relationships, and who give their advisors the chance to express their style or expectations, may find it easier to approach difficult conversations or to address challenges that may arise. We encourage conducting a needs assessment with the advisor/supervisor as a way to establish expectations and goals for the working relationship moving forward (Baker, Pifer, \& Griffin, 2014; Vaquera, 2007). As students balance teaching, research, publishing, and the other facets of doctoral training, talking about these experiences with peers and faculty members becomes important and can ease the stress associated with maintaining a careful balance between personal and professional responsibilities during the transitions of Stage 2 (Fenge, 2012; Jairam \& Kahl, 2012; McDaniels, 2010; Pearson, Cumming, Evans, Macauley, \& Ryland, 2011). Fellow students can provide formal support such as writing groups as well as informal support and friendship (Aitchison, 2009; Martinsuo \& Turkulainen, 2011; Pilbeam, LloydJones, \& Denyer, 2013).

\section{Stage 2 strategies for faculty members}

We encourage faculty members to consider how the challenges of Stage 2 may occur in their programs and disciplines. Understanding students' goals, skills, and progress will also allow faculty members to advocate for and contribute to student success. It may help faculty members to remember that the lack of structure in Stage 2 can prompt a time of adjustment. One way to counter this is to seek regular updates on progress towards degree completion. Creating opportunities for students to learn professional skills, such as teaching, through experience, observation, and conversation are also important ways for faculty members to support student learning and career goal 
development (McDaniels, 2010). Faculty members might also consider the value of signature pedagogies for student learning within their disciplines during the second stage of the process (Golde, 2007). Students learn a great deal about how to manage the rigors of doctoral education by observing veteran members of the academic community. Displaying disciplinarily norms and behaviors - as well as sharing stories with students during social events, seminars, or one-on-one interactions - are vitally important to student success during this stage. Additional strategies for supporting students in Stage 2 include regular updates to program curricula in light of emerging professional knowledge and trends, and clear curricular paths for students representing diverse career goals (Wampler, 2010). As students complete their coursework, including research methods courses, and continue to develop their researcher identities and skills through assistantships, apprenticeships, and the initial development of their thesis proposals, it is also important for faculty members to facilitate students' research skill development at this stage (Kayama et al., 2013; Rogers \& Goktas, 2010).

\section{Stage 2 strategies for administrators}

Administrative support is crucial for student success in Stage 2. Program administrators can formalize social and professional events that are particularly relevant for students, such as Michigan State University's Planning, Resilience, Engagement, and Professionalism (PREP) Program. As students make the transition to independence, they may feel disconnected from the department or program. Providing a reason to remain connected to the community and physically present in the space where they can interact with peers and faculty can help counter feelings of transition and isolation. Current, accurate, and accessible information about how to change an advisor, how to form a dissertation committee, or how to schedule a proposal defense can help alleviate students' feelings of doubt or confusion about how to move forward in this stage. Administrators can also lend their support by publicizing students' research interests, publications, and presentations in the program or department, institution, and discipline. They can also work with student organizations, development offices, or public relations offices to further publicize student achievements and scholarly activity (McAlpine \& Amundsen, 2012). Formal programs that provide structured opportunities for professional skill development - within teaching (McDaniels, 2010), research (Weidman, 2010), and service (Ward, 2010) - can also be administered to support doctoral student experiences in this stage.

\section{Stage 3: Knowledge Enactment}

In the final stage of doctoral education, knowledge enactment, students enact the technical and sociocultural knowledge they have acquired to engage in the role of the scholar. This occurs through the dissertation research and writing process, the successful defense of the dissertation, the job search process, and obtaining employment. The dissertation experience may serve as a source of stress as the final task separating students from degree completion and as the marker of their membership in the community of scholars (Gardner, 2009b). During the knowledge enactment stage, doctoral candidates continue to refine their abilities and identities as students, while also engaging in a parallel process of identity development as emergent scholars (Baker \& Pifer, 2014). Candidates must continue to engage in their roles as students, which may present a conflict, as they must also position themselves as researchers and scholars in their own right. This simultaneous need for support and autonomy can cause frustration and uncertainty in the final stage of the doctoral process. Students may also struggle during Stage 3 to create and mobilize their professional networks as they prepare to begin their post-degree careers. Stress over the job search and the transition out of graduate school and into their professional roles can also be challenging. These professional stressors can also contribute to feelings of isolation, distance from friends and family members, and shifts in personal relationships (Pifer \& Baker, 2014; Sorrell Dinkins \& Merkle Sorrell, 2014). 


\section{Stage 3 strategies for students}

In the dissertation process, students may benefit from clear strategies to manage their time and progress towards completion, such as establishing daily, weekly, and monthly goals (Roberts, 2010). This approach can help students feel more in control of larger tasks inherent in the process, while also creating small wins to help students feel motivated. Communicating with personal and professional supporters can help students in Stage 3 feel connected to their communities and secure in their relationships, while also informing others of what they are experiencing. It may be helpful for students to consider how work habits may influence feelings of isolation; while the nature of Stage 3 productivity often facilitates working from home or other remote locations, this can detract from students' sense of community and connectedness (McAlpine \& Mitra, 2015). The second major task of Stage 3, the job search, also requires both independent goals and collaboration with advisors and others. Securing opportunities to publish and present one's work and otherwise engage in scholarly activity is an important component of preparing for the academic job market (Teeuwsen, Ratković, \& Tilley, 2014; Yerkes et al., 2012). Experiences such as teaching, journal editing, and participating in research are also instrumental in students' professional preparation and education (Hopwood, 2010). We encourage students to engage in knowledge enactment, as the Stage 3 descriptor suggests. This may mean scheduling practice job talks, seeking friendly reviews for manuscript drafts, and networking to identify future collaborations. Students must engage as professionals in their intended careers, whether in the professoriate or other roles.

\section{Stage 3 strategies for faculty members}

We encourage faculty members to think deliberately about the student experience in Stage 3 and their ability to actively support students during this time. The major academic task of this stage is the dissertation, and effective advising relationships remain critical. This might include providing technical or administrative guidance; helping students manage relationships with project supervisors, committee members, or others during this high-stakes time; and engaging in dialogue with students as they navigate the dissertation process. Modeling and supporting intellectual curiosity and freedom is another important component of faculty engagement as students explore their researcher identities (Gonzalez \& Marin, 2002). Faculty members are invaluable in helping students develop professional networks as they progress through Stage 3 (Baker \& Pifer, 2011; McAlpine \& Amundsen, 2012). One of the most important resources faculty members can offer to their students during this stage is their academic capital by making introductions and recommending students for positions. Another important area is mentoring for diverse career goals. Faculty members serve as trusted advisors in students' transitions to their scholarly roles and students may be underinformed or misinformed about the academic profession and labor market. Prior research has document students' interest in practical advice and realistic previews of the academic profession in its various iterations (Baker \& Pifer, 2014; Council of Graduate Schools and Educational Testing Service, 2010; Nerad, Aanerud, \& Cerny, 2006; Solem et al., 2009; Treptow, 2013; Ward, 2010). As the academic job market continues to change, and as global economic forces continue to affect career goals, training requirements, and employment opportunities, academic programs would be well served to become more effective in cultivating administrators, educators, researchers, and other types of professionals beyond the traditional but more narrowly construed concept of the scholar to adequately address the needs and future roles of today's doctoral learners (Anastas \& Kuerbis, 2009; Golovushkina \& Milligan, 2012; Lee \& Fottler, 2007; Porter \& Phelps, 2014). Such efforts may include cultivating internship opportunities or clinical experiences for students who intend to pursue nonacademic careers, such as those described by Miller, Todahl, Platt, Lambert-Shute, and Eppler (2010). This is another way in which faculty members' networks become important resources for supporting and educating doctoral students (O'Meara et al., 2014). 


\section{Stage 3 strategies for administrators}

To support students in Stage 3, program and department administrators might emphasize structured, formal guidance for students transitioning from the student-as-learner role to that of scholar-as-learner. This might include practice job talks, workshops about the logistics of the job search, or guided opportunities to write for publication. Similarly, investments of resources to support student employment through learning-based experiences such as teaching and research assistantships provide necessary opportunities that will help doctoral students to prepare for their careers (Hopwood, 2010). While this may already be common practice in some disciplines and institutions, signaling an investment in student success through administrative support for these practical tools or similar discipline-specific strategies may be of great support to students (Baker \& Pifer, 2014; O’Meara et al., 2014).

\section{Challenges Across Stages}

Certain challenges of doctoral education do not rest in any particular stage. These challenges relate to students' complex identities and layered sense of fit, and to their interactions with others and their personal and professional networks of relationships. A lack of fit may negatively affect doctoral students at various levels, including within their programs or departments, their institutions, and their disciplines and professions. When students perceive themselves to be different from either key individuals such as advisors or key referent groups such as cohorts or department members, they may discount their ability to achieve program completion and/or obtain resources such as support, research opportunities, and professional networks. These perceptions of difference occur across all aspects of students' identities, including but not limited to their professional and academic roles (Ampaw \& Jaeger, 2012; Baker et al., 2014; Gardner \& Gopaul, 2012;

Hopwood \& Paulson, 2012; Solem et al., 2009; Teeuwsen et al., 2014). Identity-based challenges also include those outside of students' perceptions, as reflections of social structures and trends. For example, in the United States, students of color earn doctorates and academic appointments less often than White students and have reported qualitatively different experiences than their White peers (Antony \& Taylor, 2004; Barnes \& Wells, 2009; Felder \& Barker, 2013; Felder, Stevenson, \& Gasman, 2014; González, 2006; Winkle-Wagner, Johnson, Morelon-Quainoo, \& Santiague, 2010). Gender has also been documented as a factor that influences doctoral students' experiences, interactions, and challenges (Barnes \& Wells, 2009; Erickson, 2012; Haynes et al., 2012; Sallee, 2010). The task of balancing personal and familial roles and responsibilities during the doctoral journey also presents challenges across the stages, including for full-time and parttime students, for single and partnered students, and also for both childless and parenting students (Byers et al., 2014; Kärner et al., 2005; Martinez, Ordu, Della Sala, \& McFarlane, 2013; Millett $\&$ Nettles, 2010; Pearson et al., 2011; Pifer \& Baker, 2014). According to one study, $43 \%$ of students who leave graduate programs do so for personal or family-related reasons (Nevill \& Chen, 2007). The doctoral journey will, in addition, introduce its own changes and challenges to personal relationships and family roles (Gardner \& Gopaul, 2012; Russell, 2015; Washburn-Moses, 2008; Vekkaila et al., 2013).

\section{Student strategies across stages}

Across stages, it is important for students to be reflective about the ways in which their identities and program cultures contribute to, or detract from, a sense of fit in the contexts of their doctoral studies (Baker \& Pifer, 2015). The needs assessment may combat students' tendency to seek out mentors and advisors based on similarity, instead of fit, which may actually decrease student satisfaction and success (Baker, Pifer, \& Griffin, 2014; Gonzalez \& Marin, 2002). Peer support and socializing has been shown to be a contributor to doctoral student persistency (Brill et al., 2014; Herzig, 2004; Jairam \& Kahl, 2012; Nettles \& Millett, 2006; Russell, 2015; Sugimoto, 2012; 
Zahl, 2015). Fellow students represent an important source of learning and have the rare ability to share in students' challenges and successes within programmatic and disciplinary contexts.

For both full-time and part-time students, the challenges and changes of everyday life are not always avoidable during the doctoral journey. Seeking developmental networks of support and communicating with friends and family outside of one's academic program or department are strategies that may help students with this aspect of the journey towards completion (Jairam \& Kahl, 2012; Pifer \& Baker, 2014; Sweitzer, 2009). We also encourage students to develop and enact a sense of personal agency. Doctoral education is in many ways an independent process. The ability to act with agency and be the drivers of their own success, particularly in the face of challenges, is critical (Anderson, Cutright, \& Anderson, 2013; Baker \& Pifer, 2014; Herzig, 2004; Martinsuo \& Turkulainen, 2011; McAlpine \& Amundsen, 2012; McAlpine \& Mitra, 2015; O’Meara et al., 2014; Platow, 2012; Rockinson-Szapkiw, Spaulding, Swezey, \& Wicks, 2014). This may be achieved through steps such as establishing and taking ownership of goals, obtaining clarity about expectations, and seeking help when needed. If students and their teams of developers and supporters can communicate openly about the challenges of doctoral education, it may reduce the negative effects of these challenges substantially.

\section{Faculty strategies across stages}

Research indicates clearly that students experience unique challenges within each change, and also at the transition points between stages and in general ways across stages (Ampaw \& Jaeger, 2012; Vekkaila et al., 2013). In response to general challenges across stages, faculty members might reflect on the ways in which they establish and cultivate developmental relationships with students. Students who perceive themselves as the other also perceive that they do not have the same opportunities as peers, and thus experience greater challenges than those who may experience a strong personal or professional fit within their programs (Herzig, 2004; Hopwood \& Paulson, 2012; Pifer \& Baker, 2014; Teeuwsen et al., 2014). While similarity to faculty members has been shown to foster academic connections for doctoral students (Main, 2014; Olalere, De Iulio, Aldarbag, \& Erdener, 2014; Ugrin, Odom, \& Pearson, 2008), a lack of perceived fit or sameness can cause students to doubt themselves and their ability to secure faculty support for their work (Antony \& Taylor, 2004; Felder \& Barker, 2013; Gonzalez \& Marin, 2002; Pifer \& Baker, 2014; Russell, 2015; Zahl, 2015).

Attention to fit focuses on shared professional values and goals between faculty members and students rather than perceived sameness, which can be an inaccurate predictor of compatibility in faculty-student relationships (Baker et al., 2014). Reminding students as emerging scholars that learning is an ongoing part of the process of being a scholar can also help communicate to students that they should feel comfortable in their roles as emerging scholars and that professional skills develop over time. Votes of confidence and encouragement from faculty members have been shown to be critical for countering students' feelings of self-doubt and discouragement (Byers et al., 2014; Vekkaila et al., 2013).

Faculty members are also uniquely positioned to shape program culture and traditions, as well as patterns of informal and formal interaction, which are instrumental in cultivating support structures and networks of relationships for students (Brill et al., 2014; Lovitts, 2005; Solem et al., 2009; Weidman et al., 2001). Research has shown that social interaction with faculty members is particularly important for student success (Anderson et al., Baker et al., 2013; Jairam \& Kahl, 2012; Nettles \& Millett, 2006; Sugimoto, 2012; Ugrin et al., 2008; Washburn-Moses, 2008; Walker et al., 2008). Supporting doctoral learners is no easy feat - scholars remind us that in addition to these recommended social and developmental strategies, faculty members are also commissioned to deliver high-quality training and to maintain academic and scientific rigor through their roles preparing scholars (Bøgelund, 2015; Elkana, 2006; Golde \& Dore, 2004; 
Teeuwsen et al., 2014; Vaquera, 2007), while simultaneously supporting their development beyond the traditional roles of teaching, research, and service to account for the realities of the academy (A. E. Austin, 2003; Celik, 2013; Malfroy, 2011; Platow, 2012).

\section{Administrative strategies across stages}

Administrators are key in establishing and fulfilling the mission, purposes, and processes of doctoral education. Deans and others within the disciplines are particularly well positioned to serve leadership roles in strengthening doctoral programs within their academic areas (De Lisi, 2013). Administrators might also be deliberate about discussing the challenges of doctoral education with faculty members to educate and inform graduate faculties and to foster a shared commitment to support students (McAlpine \& Amundsen, 2012; O'Meara et al., 2014; Vaquera, 2007; Weisbuch, 2005). It may be particularly helpful to educate faculty members about best supporting students from backgrounds different from their own (Haley, Jaeger, \& Levin, 2014). Such practices may help faculty members to best serve students through the variety of roles they serve in doctoral education, including advisor, supervisor, instructor, and colleague. Given the importance of personal and professional fit, administrators might establish opportunities for dialogue with graduate faculty members about admissions processes, student retention, and the challenges to doctoral education that faculty members observe firsthand. Administrators can also demonstrate a welcoming environment to students from all backgrounds (Ballard \& Cintrón, 2010; Gonzalez \& Marin, 2002; Lovitts, 2004). They also have the opportunity to signal support to students from diverse backgrounds by creating diverse faculties through hiring practices (Felder, 2010; Vaquera, 2007).

It is also important for program administrators to avoid the assumption that each student has a positive and effective relationship with his or her advisor. Department chairs and other program administrators have the formal authority that students rely on when negotiating ineffective or challenging relationships. Tenuous relationships with faculty members can seem overwhelming (Baker \& Pifer, 2011; Vekkaila et al., 2013). Program administrators can guide the community to an understanding of the appropriate ways to manage such challenges (Lovitts, 2004; Vaquera, 2007). For example, frameworks such as Bowden and Green's (2014) moral compass model emphasize opportunities for administrators to set expectations for and, when necessary, mediate between doctoral students and supervisors.

Continuous assessment would help identify trends over time, program effectiveness, and areas for improvement (Ehrenberg, Jakubson, Groen, So, \& Price, 2007). Administrators' assessment of doctoral programs might include attention to discipline- or region-specific challenges, such as those identified by Özdemir, Arslan, and Tasçi's (2014) qualitative study of students' experiences in a nursing doctoral program in Turkey. Administrators, both within individual programs and from broader perches at school and institutional levels, are well positioned to apply their knowledge of disciplinary perspectives and norms related to research, funding models, curricular requirements, and student success to specific strategies for supporting doctoral student and faculty efforts within disciplines and programs (Gardner, 2009a). In general, fulfillment of administrative responsibilities and opportunities for program improvement is a necessary contribution towards excellence in doctoral education (Prewitt, 2006; Weisbuch, 2005).

\section{Discussion}

We embarked on the creation of this manuscript to respond to the call of Wulff, Austin, and associates (2004) to think more practically and critically about the paths to the professoriate. Through this analysis, we offer strategies to support the key constituents in doctoral education - doctoral students, faculty members, and administrators. This study serves as a meta-analytic review of research about the doctoral student experience from 2000 to the present. As such, this study's 
findings contribute to the scholarly literature about doctoral education, knowledge about the academy and the doctoral enterprise domestically and abroad, and information about stakeholders' perspectives and roles in the doctoral process as it occurs locally within programs. Studies about doctoral student experiences are predominantly qualitative in nature, and often at the individual program level. This article synthesizes the findings and recommendations and presents themes across disciplinary, programmatic, institutional, and national contexts.

The stage model approach facilitates the identification of characteristics and milestones and the associated challenges, strategies, and needed supports. Researchers have relied on stage models to better understand, assess, and support doctoral student development (Nettles \& Millet, 2006; Tinto, 1993; Weidman et al., 2001). These models established and described the stages through which students transition, but often did not explore the student as situated within those stages or the behavioral strategies associated with each stage. Rather, past doctoral research has predominantly explored the stages independently to identify their characteristics and related student experiences (A. E. Austin \& McDaniels, 2006; Gardner, 2008; Golde, 1998; Lovitts, 2005, 2008). This research is the first we are aware of that explores all three stages through a practice-based synthesis of existing research to offer insights and strategies within and among the three stages to key stakeholders. Additionally, we emphasize Stage 3 as a critical period of knowledge enactment (Baker \& Pifer, 2014) and include recommendations for success related to mastery and enactment of the skills necessary for independent learning and knowledge creation as students transition out of the final stage of the doctoral process and into their postdoctoral careers.

Another contribution of this article is its synthesis of research about doctoral student experiences across disciplinary areas and national contexts. Paths to the doctorate vary based on disciplinary differences, program mission and purpose, and national context. Our reliance on stages allows us to take a broader view of the doctoral student experience, as all students move through transition points as they progress towards program completion. The stage approach supports the creation of a common language with which we can compare and study doctoral programs and the doctoral student experience from a global perspective. As research emerges from non-US models, such as Cross and Backhouse's (2014) consideration of evaluation strategies for doctoral programs in Africa and as the Austrian efforts described by Pechar, Ates, and Andres (2012), continued research and consideration of its applicability to practice will be essential.

Research about emergent doctoral program models such as those described by Lee, Scutchfield, and Hill (2007) and Biegel, Hokenstad, Singer, and Guo (2006) also points to the need to continuously reassess not only how we engage in doctoral education and study it, but also how we strengthen the lines of communication between research and practice towards improvement that favors both innovation and tradition. For example, while the dissertation remains a meaningful model of preparing emergent scholars in many disciplines and institutions, the evolving nature of the doctorate warrants attention to whether and how the dissertation experience might be altered in ways that promote skill development, knowledge acquisition, and career preparation. Additional research and reconsideration of formal practices and informal strategies for student support is needed.

\section{Conclusion}

It is our hope that the recommendations offered here initiate discussions and action in response to the challenges of doctoral education identified by research, as they manifest themselves in specific programs, disciplines, and institutions. We advocate for continued improvement in doctoral education through these strategies and for continued dialogue between scholars of doctoral education and those who participate in it, with the aim of improving individual experiences, academic programs, and the preparation of well-trained professionals across the disciplines and diverse career paths. While the responsibility for success lies with the student, doctoral education can be a 
time of self-doubt, uncertainty, and hesitation to ask for support. Effectively communicated policies and guidelines, regular feedback, cultures of acceptance and support, and investments of resources are strategies that faculty members and administrators can employ to promote student success and program effectiveness. We remind students, faculty members, and administrators of the importance of understanding each stage, thus becoming aware of the challenges students may experience as they transition through their doctoral programs. We encourage proactive responses to those challenges, including open communication between and among stakeholders, policies and practices to guide students through the stages, affirmation of students' development as both learners and professionals, and cultivation of developmental networks that provide support. A small interaction, an expression of interest, the offering of guidance, an invitation to participate, and a space for reflection can be the difference between success and failure on the journey toward the doctorate.

\section{References}

Adegbola, M. (2011). Soar like geese: Building developmental network relationships for scholarship. Nursing Education Perspectives, 32(1), 51-53.

Aitchison, C. (2009). Writing groups for doctoral education. Studies in Higher Education, 34(8), 905-916.

Ampaw, F. D., \& Jaeger, A. J. (2012). Completing the three stages of doctoral education: An event history analysis. Research in Higher Education, 53(6), 640-660. doi:http://dx.doi.org/10.1007/s11162-0119250-3

Anastas, J. W., \& Kuerbis, A. N. (2009). Doctoral education in social work: What we know and what we need to know. Social Work, 54(1), 71-81.

Anderson, B., Cutright, M., \& Anderson, S. (2013). Academic involvement in doctoral education: Predictive value of faculty mentorship and intellectual community on doctoral education outcomes. International Journal of Doctoral Studies, 8, 195-201. Retrieved from http://ijds.org/Volume8/IJDSv8p195215Anderson0405.pdf

Antony, J. S., \& Taylor, E. (2004). Theories and strategies of academic career socialization: Improving paths to the professoriate for Black graduate students. In D. H. Wulff \& A. E. Austin (Eds.), Paths to the professoriate: Strategies for enriching the preparation of future faculty (pp. 92-114). San Francisco, CA: Jossey Bass.

Austin, A. E. (2003). Creating a bridge to the future: Preparing new faculty to face changing expectations in a shifting context. The Review of Higher Education, 26(2), 119-144.

Austin, A. E., \& McDaniels, M. (2006). Preparing the professoriate of the future: Graduate student socialization for faculty roles. In J. C. Smart (Ed.), Higher Education: Handbook of Theory and Research, vol. 21 (pp. 397-456). Netherlands: Springer.

Austin, J., Cameron, T., Glass, M., Kosko, K., Marsh, F., Abdelmagid, R., \& Burge, P. (2009). First semester experiences of professionals transitioning to full-time doctoral study. College Student Affairs Journal, 27(2), 194-214.

Bair, C. R., Haworth, J. G., \& Sandfort, M. (2004). Doctoral student learning and development: A shared responsibility. Journal of Student Affairs Research and Practice, 41(4), 1277-1295.

Baker, V. L., \& Pifer, M. J. (2011). The role of relationships in the transition from doctoral student to scholar. Studies in Continuing Education, 33(1), 5-17. doi: 10.1080/0158037X.2010.515569

Baker, V. L., \& Pifer, M. J. (2014). Preparing for practice: Parallel processes of identity development in stage 3 of doctoral education. International Journal of Doctoral Studies, 9, 137-154. Retrieved from http://ijds.org/Volume9/IJDSv9p137-154Baker0623.pdf

Baker, V. L., \& Pifer, M. J. (2015). Antecedents and outcomes: Theories of fit and the study of doctoral education. Studies in Higher Education, 40(2), 296-310. doi: 10.1080/03075079.2013.823936 
Baker, V. L., Pifer, M. J., \& Flemion, B. (2013). Process challenges and learning-based interactions in stage 2 of doctoral education: Implications from two applied social science fields. The Journal of Higher Education, 84(4), 449-476. doi: 10.1353/jhe.2013.0024

Baker, V. L., Pifer, M. J., \& Griffin, K. A. (2014). Mentor-protégé fit: Identifying and developing effective mentorship across identities in doctoral education. International Journal for Researcher Development, 5(2), 83-98. doi: 10.1108/IJRD-04-2014-0003

Ballard, H. E., \& Cintrón, R. (2010). Critical race theory as an analytical tool: African American male success in doctoral education. Journal of College Teaching and Learning, 7(10), 11-23.

Barnes, B. J., \& Austin, A. E. (2009). The role of doctoral advisors: A look at advising from the advisor's perspective. Innovative Higher Education, 33(5), 297-315.

Barnes, B. J., \& Wells, C. S. (2009). Differential item functional analysis by gender and race of the national doctoral program survey. International Journal of Doctoral Studies, 4, 77-96. Retrieved from http://www.ijds.org/Volume4/IJDSv4p077-096Barnes258.pdf

Biegel, D. E., Hokenstad, M. C., Singer, M. I., \& Guo, S. (2006). One school's experience in reconceptualizing part-time doctoral education in social work. Journal of Social Work Education, 42(2), 231-247.

Bøgelund. P. (2015). How supervisors perceive PhD supervision - And how they practice it. International Journal of Doctoral Studies, 10, 39-55. Retrieved from http://ijds.org/Volume10/IJDSv10p039055Bogelund0714.pdf

Bowden, J. A., \& Green, P. (2014). A moral compass framework for resolution of wicked problems in doctoral education and supervision. Quality Assurance in Education, 22(4), 355-369.

Brailsford, I. (2010). Doctoral completion: Can history teach us anything? New Zealand Journal of Educational Studies, 45(2), 61-74.

Brill, J. L., Balcanoff, K. K., Land, D., Gogarty, M. M., \& Turner, F. (2014). Best practices in doctoral retention: Mentoring. Higher Learning Research Communications, 4(2), 26-37.

Byers, V. T., Smith, R. N., Hwang, E., Angrove, K. E., Chandler, J, I., Christian, K. M., ... Onwuegbuzie, A. J. (2014). Survival strategies: Doctoral students' perceptions of challenges and coping methods. International Journal of Doctoral Studies, 9, 109-136. Retrieved from http://ijds.org/Volume9/IJDSv9p109-136Byers0384.pdf

Celik, K. (2013). The contribution of supervisors to doctoral students in doctoral education: A qualitative study. Creative Education, 4(1), 9-17.

Cohen, P. (2006). The writing on the wall: Doctoral education in Texas and elsewhere. Change: The Magazine of Higher Learning, 38(6), 42-48.

Council of Graduate Schools and Educational Testing Service. (2010). The Path Forward: The Future of Graduate Education in the United States. Report from the Commission on the Future of Graduate Education in the United States. Princeton, NJ: Educational Testing Service.

Cross, M., \& Backhouse, J. (2014). Evaluating doctoral programmes in Africa: Context and practices. Higher Education Policy, 27(2), 155-174. doi:http://dx.doi.org/10.1057/hep.2014.1

Dall'Alba, G. \& Sandberg, J. (2006). Unveiling professional development: A critical review of stage models. Review of Educational Research, 76(3), 383-412.

De Lisi, R. (2013). Reflection, reconstruction, and transformation of the EdD: A dean's perspective. Planning and Changing, 44(3), 127-139.

Doan, W. J., Nathans, H. S., Anderson, P., \& Bial, H. (2013, 14 February). Sustaining the doctorate in theater. The Chronicle of Higher Education. Retrieved from http://chronicle.com/article/Sustaining-theDoctorate-in/137265/ 
Ehrenberg, R. G., Jakubson, G. H., Groen, J. A., So, E., \& Price, J. (2007). Inside the black box of doctoral education: What program characteristics influence doctoral students' attrition and graduation probabilities? Educational Evaluation and Policy Analysis, 29(2), 134-150.

Elkana, Y. (2006). Unmasking uncertainties and embracing contradictions. In C. M. Golde \& G. E. Walker (Eds.), Envisioning the future of the doctorate: Preparing stewards of the discipline. (pp. 65-96). San Francisco, CA: Jossey-Bass.

Erickson, S. K. (2012). Women Ph. D. students in engineering and a nuanced terrain: Avoiding and revealing gender. The Review of Higher Education, 35(3), 355-374.

Felder, P. (2010). On doctoral student development: Exploring faculty mentoring in the shaping of African American doctoral student success. The Qualitative Report, 15(2), 455-474.

Felder, P. P., \& Barker, M. J. (2013). Extending Bell's concept of interest convergence: A framework for understanding the African American doctoral student experience. International Journal of Doctoral Studies, 8, 1-20. Retrieved from http://ijds.org/Volume8/IJDSv8p001-020Felder0384.pdf

Felder, P. P., Stevenson, H. C., \& Gasman, M. (2014). Understanding race in doctoral student socialization. International Journal of Doctoral Studies, 9, 21-42. Retrieved from http://ijds.org/Volume9/IJDSv9p021-042Felder0323.pdf

Fenge, L. A. (2012). Enhancing the doctoral journey: The role of group supervision in supporting collaborative learning and creativity. Studies in Higher Education, 37(4), 401-414.

Gardner, S. K. (2008). "What's too much and what's too little?": The process of becoming an independent researcher in doctoral education. The Journal of Higher Education, 79(3), 326-350.

Gardner, S. K. (2009a). Conceptualizing success in doctoral education: Perspectives of faculty in seven disciplines. Review of Higher Education, 32(3), 383-406.

Gardner, S. K, (2009b). The development of doctoral students: Phases of challenge and support. ASHE Higher Education Report, 34(6). San Francisco, CA: Jossey-Bass.

Gardner, S. K., \& Gopaul, B. (2012). The part-time doctoral student experience. International Journal of Doctoral Studies, 7, 63-78.

Golde, C. M. (1998). Beginning graduate school: Explaining first-year doctoral attrition. New Directions for Higher Education, 101, 55-64.

Golde, C. M. (2000). Should I stay or should I go? Student descriptions of the doctoral attrition process. The Review of Higher Education, 23(2), 199-227.

Golde, C. M. (2005). The role of the department and discipline in doctoral student attrition: Lessons from four departments. The Journal of Higher Education, 76(6), 669-700.

Golde, C. M. (2007). Signature pedagogies in doctoral education: Are they adaptable for the preparation of education researchers? Educational Researcher, 36(6), 344-351.

Golde, C. M., \& Dore, T. M. (2004). The survey of doctoral education and career preparation: The importance of disciplinary contexts. In D. H. Wulff \& A. E. Austin (Eds.), Paths to the professoriate: Strategies for enriching the preparation of future faculty (pp. 19-45). San Francisco, CA: Jossey Bass.

Golde, C. M., \& Walker, G. E. (Eds.) (2006). Envisioning the future of the doctorate: Preparing stewards of the discipline. San Francisco, CA: Jossey-Bass.

Golovushkina, E., \& Milligan, C. (2012). Developing early stage researchers. International Journal for Researcher Development, 3(1), 64-78. doi:http://dx.doi.org/10.1108/17597511211278652

González, J. C. (2006). Academic socialization experiences of Latina doctoral students: A qualitative understanding of support systems that aid and challenges that hinder the process. Journal of Hispanic Higher Education, 5(4), 347-365.

Gonzalez, K. P., \& Marin, P. (2002). Inside doctoral education in America: Voices of Latinas/os in pursuit of the PhD. Journal of College Student Development, 43(4), 540-557. 
Haley, K. J., Jaeger, A. J., \& Levin, J. S. (2014). The influence of cultural social identity on graduate student career choice. Journal of College Student Development, 55(2), 101-119.

Haynes, C., Bulosan, M., Citty, J., Grant-Harris, M., Hudson, J., \& Koro-Ljungberg, M. (2012). My world is not my doctoral program... or is it? Female students' perceptions of well-being. International Journal of Doctoral Studies, 7(1), 1-17. Retrieved from http://ijds.org/Volume7/IJDSv7p001017Haynes329.pdf

Heathcott, J. (2007) Blueprints, tools, and the reality before us: Improving doctoral education in the humanities. Change: The Magazine of Higher Learning, 39(5), 46-51.

Herzig, A. H. (2004). Becoming mathematicians: Women and students of color choosing and leaving doctoral mathematics. Review of Educational Research, 74(2), 171-214.

Holbrook, A., Shaw, K., Scevak, J., Bourke, S., Cantwell, R., \& Budd, J. (2014). PhD candidate expectations: Exploring mismatch with experience. International Journal of Doctoral Studies, 9, 329-346. Retrieved from http://ijds.org/Volume9/IJDSv9p329-346Holbrook0575.pdf

Hopwood, N. (2010). Doctoral experience and learning from a sociocultural perspective. Studies in Higher Education, 35(7), 829-843.

Hopwood, N., \& Paulson, J. (2012). Bodies in narratives of doctoral students' learning and experience. Studies in Higher Education, 37(6), 667-681.

Hutchings, P., \& Clarke, S. E. (2004). The scholarship of teaching and learning: Contributing to reform in graduate education. In D. H. Wulff \& A. E. Austin (Eds.), Paths to the professoriate: Strategies for enriching the preparation of future faculty (pp. 161-176). San Francisco, CA: Jossey Bass.

Jairam, D., \& Kahl, D. H. (2012). Navigating the doctoral experience: The role of social support in successful degree completion. International Journal of Doctoral Studies, 7, 311-329. Retrieved from http://ijds.org/Volume7/IJDSv7p311-329Jairam0369.pdf

Jones, M. (2013). Issues in doctoral studies - forty years of journal discussion: Where have we been and where are we going? International Journal of Doctoral Studies, 8, 83-104. Retrieved from http://ijds.org/Volume8/IJDSv8p083-104JonesFT129.pdf

Kayama, M., Gregg, M. F, Asahara, K., Yamamoto-Mitani, N., Okuma, K., Ohta, K., \& Kinoshita, Y. (2013). Mentoring doctoral students for qualitative research: Interviews with experienced nursing faculty in Japan. Journal of Nursing Education, 52(5), 283-289.

Kärner, A., Kukemelk, H., \& Herdlein, R. J. (2005). Motivation for obtaining the Doctor of Philosophy degree in the post-Soviet era: The case of Estonia. International Education, 35(1), 24-34, 63-64.

Labi, A. (2010, 6 June). As doctoral education in Europe evolves, educators meet to chart its progress. The Chronicle of Higher Education. Retrieved from http://chronicle.com/article/As-Doctoral-Educationin/65799/

Lee, J. M., \& Fottler, M. D. (2007). The status of national and health administration doctoral education: Issues for the 21st century. The Journal of Health Administration Education, 24(3), 187-199.

Lee, J. M., Scutchfield, F. D., \& Hill, R. R. (2007). The Kentucky plan revisited: Lessons learned from an innovative doctoral education program. The Journal of Health Administration Education, 24(3), 269281.

Lovitts, B. E. (2001). Leaving the ivory tower: The causes and consequences of departure from doctoral study. Lanham, MD: Rowman \& Littlefield.

Lovitts, B. E. (2004). Research on the structure and practice of graduate education: Retaining students. In D. H. Wulff \& A. E. Austin (Eds.), Paths to the professoriate: Strategies for enriching the preparation of future faculty (pp. 115-136). San Francisco, CA: Jossey Bass.

Lovitts, B. E. (2005). Being a good course-taker is not enough: A theoretical perspective on the transition to independent research. Studies in Higher Education, 30(2), 137-154. 
Lovitts, B. E. (2008). The transition to independent research: Who makes it, who doesn't, and why. The Journal of Higher Education, 79(3), 296-325.

Main, J. B. (2014). Gender homophily, Ph.D. completion, and time to degree in the humanities and humanistic social sciences. Review of Higher Education, 37(3), 349-375.

Malfroy, J. (2011). The impact of university-industry research on doctoral programs and practices. Studies in Higher Education, 36(5), 571-584.

Martinez, E., Ordu, C., Della Sala, M. R., \& McFarlane, A. (2013). Striving to obtain a school-work-life balance: The full-time doctoral student. International Journal of Doctoral Studies, 8, 39-59. Retrieved from http://ijds.org/Volume8/IJDSv8p039-059Martinez0375.pdf

Martinsuo, M., \& Turkulainen, V. (2011). Personal commitment, support and progress in doctoral studies. Studies in Higher Education, 36(1), 103-120.

McAlpine, L., \& Amundsen, C. (2012). Challenging the taken-for-granted: How research analysis might inform pedagogical practices and institutional policies related to doctoral education. Studies in Higher Education, 37(6), 683-694.

McAlpine, L., \& Mitra, M. (2015). Becoming a scientist: PhD workplaces and other sites of learning. International Journal of Doctoral Studies, 10, 111-128. Retrieved from http://ijds.org/Volume10/IJDSv10p111-128McAlpine0768.pdf

McDaniels, M. (2010). Doctoral student socialization for teaching roles. In S. K. Gardner \& P. Mendoza (Eds.), On becoming a scholar: Socialization and development in doctoral education (pp. 29-44). Sterling, VA: Stylus.

Miller, J. K., Todahl, J., Platt, J. J., Lambert-Shute, J., \& Eppler, C. S. (2010). Internships for future faculty: Meeting the career goals of the next generation of educators in marriage and family therapy. Journal of Marital and Family Therapy, 36(1), 71-79.

Millett, C. M., \& Nettles, M. T. (2010). The Ph.D. degree and the marriage license: A good pairing for socializing students to doctoral education? In S. K. Gardner \& P. Mendoza (Eds.), On becoming a scholar: Socialization and development in doctoral education (pp. 157-178). Sterling, VA: Stylus.

National Science Foundation. (n.d.) About the National Center for Science and Engineering Statistics (NCSES). Retrieved from http://www.nsf.gov/statistics/about-ncses.cfm

National Science Foundation, National Center for Science and Engineering Statistics. (2015). Women, minorities, and persons with disabilities in science and engineering: 2015. Special Report NSF 15-311. Arlington, VA. Available at http://www.nsf.gov/statistics/wmpd/

Nettles, M. T., \& Millett, C. M. (2006). Three magic letters: Getting to Ph.D. Baltimore, MD: The Johns Hopkins University Press.

Nerad, M., Aanerud, R., \& Cerny, J. (2004). "So you want to become a professor!" Lessons from the PhDsten years later study. In D. H. Wulff \& A. E. Austin (Eds.), Paths to the professoriate: Strategies for enriching the preparation of future faculty (pp. 137-158). San Francisco, CA: Jossey Bass.

Nevill, S. C., \& Chen, X. (2007). The path through graduate school: A longitudinal examination 10 years after bachelor's degree. (NCES No. 2007-162). Washington, DC: National Center for Education Statistics, US Department of Education.

Özdemir, H., Arslan, S. Y., \& Tasçi, S. (2014). A qualitative study about nursing doctoral education in Turkey. International Journal of Caring Sciences, 7(2), 547-552.

Olalere, A. A., De Iulio, E., Aldarbag, A. M., \& Erdener, M. A. (2014). The dissertation topic selection of doctoral students using dynamic network analysis. International Journal of Doctoral Studies, 9, 85107. Retrieved from http://ijds.org/Volume9/IJDSv9p085-107Olalere521.pdf

O’Meara, K., Jaeger, A., Eliason, J., Grantham, A., Cowdery, K., Mitchall, A, \& Zhang, K. (2014). By design: How departments influence graduate student agency in career advancement. International Jour- 
nal of Doctoral Studies, 9, 155-179. Retrieved from http://ijds.org/Volume9/IJDSv9p1551790Meara0518.pdf

Pearson, M., Cumming, J., Evans, T., Macauley, P., \& Ryland, K. (2011). How shall we know them? Capturing the diversity of difference in Australian doctoral candidates and their experiences. Studies in Higher Education, 36(5), 527-542.

Pechar, H., Ates, G., \& Andres, L. (2012). The "new doctorate" in Austria: Progress toward a professional model or status quo? CEPS Journal: Center for Educational Policy Studies Journal, 2(4), 91-110.

Pifer, M. J., \& Baker, V. L. (2014). "It could be just because I'm different": Otherness and its outcomes in doctoral education. Journal of Diversity in Higher Education, 7(1), 14-30. doi: 10.1037/a0035858

Pilbeam, C., Lloyd-Jones, G., \& Denyer, D. (2013). Leveraging value in doctoral student networks through social capital. Studies in Higher Education, 38(10), 1472-1489.

Platow, M. J. (2012). PhD experience and subsequent outcomes: A look at self-perceptions of acquired graduate attributes and supervisor support. Studies in Higher Education, 37(1), 103-118.

Porter, S. D., \& Phelps, J. M. (2014). Beyond skills: An integrative approach to doctoral student preparation for diverse careers. The Canadian Journal of Higher Education, 44(3), 54-67.

Prewitt, K. (2006). Who should do what? Implications for institutional and national leaders. In C. M. Golde \& G. E. Walker (Eds.), Envisioning the future of the doctorate: Preparing stewards of the discipline. (pp. 23-33). San Francisco, CA: Jossey-Bass.

Pruitt-Logan, A. S., \& Gaff, J. G. (2004). Preparing future faculty: Changing the culture of doctoral education. In D. H. Wulff \& A. E. Austin (Eds.), Paths to the professoriate: Strategies for enriching the preparation of future faculty (pp. 177-193). San Francisco, CA: Jossey Bass.

Roberts, C. M. (2010). The dissertation journey: A practical and comprehensive guide to planning, writing, and defending your dissertation. Corwin Press.

Rockinson-Szapkiw, A. J., Spaulding, L. S., Swezey, J., A., \& Wicks, C. J. (2014). Poverty and persistence: A model for understanding individuals' pursuit and persistence in a doctor of education program. International Journal of Doctoral Studies, 9, 181-190. Retrieved from http://ijds.org/Volume9/IJDSv9p181-203Rockinson0606.pdf

Rogers, S. W., \& Goktas, R. K. (2010). Exploring engineering graduate student research proficiency with student surveys. Journal of Engineering Education, 99(3), 263-278.

Russell, J. A. (2015). Rolling with the punches: Examining the socialization experiences of kinesiology doctoral students. Research Quarterly for Exercise and Sport, 86(2), 140-151.

Sallee, M. W. (2010). The individual and the institution: Socialization and gender. In S. K. Gardner \& P. Mendoza (Eds.), On becoming a scholar: Socialization and development in doctoral education (pp. 137-156). Sterling, VA: Stylus.

Solem, M., Lee, J., \& Schlemper, B. (2009). Departmental climate and student experiences in graduate geography programs. Research in Higher Education, 50(3), 268-292. doi:http://dx.doi.org/10.1007/s11162-008-9117-4

Sorrell Dinkins, C., \& Merkle Sorrell, J. (2014). Our dissertations, our selves: Shared stories of women's dissertation journeys. New York, NY: Palgrave MacMillan.

Stubb, J., Pyhältö, K., \& Lonka, K. (2014). Conceptions of research: The doctoral student experience in three domains. Studies in Higher Education, 39(2), 251-264.

Sugimoto, C. R. (2012). Are you my mentor? Identifying mentors and their roles in LIS doctoral education. Journal of Education for Library and Information Science, 53(1), 2-19.

Sweitzer, V. B. (2009). Towards a theory of doctoral student professional identity development: A developmental networks approach. The Journal of Higher Education, 80(1), 1-33. 
Teeuwsen, P., Ratković, S., \& Tilley, S. A. (2014). Becoming academics: Experiencing legitimate peripheral participation in part-time doctoral studies. Studies in Higher Education, 39(4), 680-694.

Tinto, V. (1993). Leaving college: Rethinking the causes and cures of student attrition. Chicago, IL: University of Chicago Press.

Treptow, R. (2013). The South African PhD: Insights from employer interviews. Perspectives in Education, 31(2), 83-91.

Ugrin, J. C., Odom, M. D., \& Pearson, J. M. (2008). Exploring the importance of mentoring for new scholars: A social exchange perspective. Journal of Information Systems Education, 19(3), 343-350.

Vaquera, G. (2007). Testing theories of doctoral student persistence at a Hispanic serving institution. Journal of College Student Retention, 9(3), 283-305.

Vekkaila, J., Pyhältö, K., \& Lonka, K. (2013). Experiences of disengagement-A study of doctoral students in the behavioral sciences. International Journal of Doctoral Studies, 8, 61-81. Retrieved from http://ijds.org/Volume8/IJDSv8p061-081Vekkaila0402.pdf

Wade-Benzoni, K., Rousseau, D. M., \& Li, M. (2006). Managing relationships across generations of academics: Psychological contracts in faculty-doctoral student collaborations. International Journal of Conflict Management, 17(1), 4-33.

Walker, G. E., Golde, C. M., Jones, L., Bueschel, A. C., \& Hutchings, P. (2008). The formation of scholars: Rethinking doctoral education for the twenty-first century. San Francisco, CA: Jossey Bass.

Wampler, K. S. (2010). Challenge and urgency in defining doctoral education in marriage and family therapy: Valuing complementary models. Journal of Marital and Family Therapy, 36(3), 291-306.

Ward, K. (2010). Doctoral student socialization for service. In S. K. Gardner \& P. Mendoza (Eds.), On becoming a scholar: Socialization and development in doctoral education (pp. 57-78). Sterling, VA: Stylus.

Wasburn-Moses, L. (2008). Satisfaction among current doctoral students in special education. Remedial and Special Education, 29(5), 259-268.

Weidman, J. C. (2010). Doctoral student socialization for research. In S. K. Gardner \& P. Mendoza (Eds.), On becoming a scholar: Socialization and development in doctoral education (pp. 45-56). Sterling, VA: Stylus.

Weidman, J C., Twale, D. J., \& Stein, E. L. (2001). Socialization of Graduate and Professional Students in Higher Education: A Perilous Passage? ASHE-ERIC Higher Education Report, 28(3). Jossey-Bass Higher and Adult Education Series. San Francisco, CA: Jossey-Bass.

Weisbuch, R. (2005). Let's keep the dean after all. Academe, 91(6), 31-33.

Winkle-Wagner, R., Johnson, S. D., Morelon-QUainoo, C., \& Santiague, L. (2010). Socialization factors that influence the transition of students of color into advanced-degree programs. In S. K. Gardner \& P. Mendoza (Eds.), On becoming a scholar: Socialization and development in doctoral education (pp. 179-202). Sterling, VA: Stylus.

Woolderink, M., Putnik, K., van der Boom, H., \& Klabbers, G. (2015). The voice of PhD candidates and $\mathrm{PhD}$ supervisors. A qualitative exploratory study amongst $\mathrm{PhD}$ candidates and supervisors to evaluate the relational aspects of $\mathrm{PhD}$ supervision in the Netherlands. International Journal of Doctoral Studies, 10, 217-235. Retrieved from http://ijds.org/Volume10/IJDSv10p217-235Woolderink0852.pdf

Woolley, S. R. (2010). Purposes, diversities, and futures in MFT doctoral education. Journal of Marital and Family Therapy, 36(3), 282-290.

Wulff, D. H., \& Austin, A. E. (2004). Paths to the professoriate: Strategies for enriching the preparation of future faculty. San Francisco, CA: Jossey Bass. 
Yerkes, M., Van de Schoot, R., \& Sonneveld, H. (2012). Who are the job seekers? Explaining unemployment among doctoral recipients. International Journal of Doctoral Studies, 7, 153-166. Retrieved from http://ijds.org/Volume7/IJDSv7p153-166Yerkes346.pdf

Zahl, S. (2015). The impact of community for part-time doctoral students: How relationships in the academic department affect student persistence. International Journal of Doctoral Studies, 10, 301-321. Retrieved from http://ijds.org/Volume10/IJDSv10p301-321Zah10672.pdf

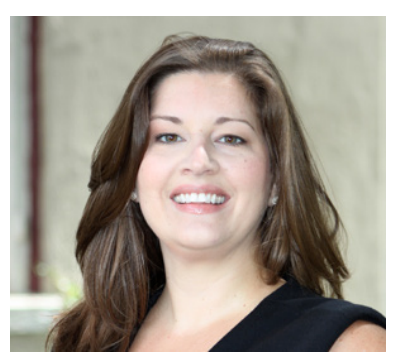

\section{Biographies}

Meghan J. Pifer is Assistant Professor of Higher Education at Widener University, where she teaches courses such as Faculty Professional Development, Teaching and Learning in Higher Education, and Organization and Governance in Higher Education. She studies faculty work and careers, graduate education and preparation for the professoriate, and equity and access in the academy.

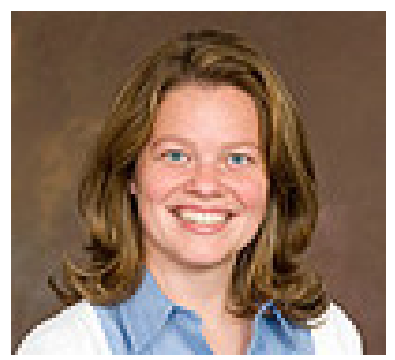

Vicki L. Baker is Associate Professor of Economics \& Management at Albion College, where she teaches courses in Management, Leadership and Organizational Behavior. Her scholarly interests include developmental networks, identity development of doctoral students, and faculty development in liberal arts colleges. 